\title{
Tinjauan Struktur Penelitian, Penulisan Ilmiah dan Teknik Penulisan Ilmiah
}

Oleh: Widya Wati, M.Pd ${ }^{*}$

\begin{abstract}
Abstrak
Banyak bentuk dan cara penulisan yang dapat ditemukan dalam berbagai pedoman penulisan. Bentuk luarnya bisa berbeda namun jiwa dan penalarannya sama. Dengan demikian yang paling penting bukan saja mengetahui teknik-teknik pelaksanaannya melainkan memahami dasar pikiran yang melandasinya. Pemilihan bentuk dan cara penulisan dari khasanah yang tersedia merupakan masalah selera dan preferensi perorangan dengan memperhatikan berbagai factor lainnya seperti masalah apa yang sedang dikaji, siapa pembaca tulisan ini dan dalam rangka kegiatan keilmuan apa karya ilmiah ini disampaikan.

Berdasarkn pemikiran tersebut maka akan coba dibahas alur-alur jalan pikiran yang terdapat dalam penelitian ilmiah yang dikaitkan dengan penulisan ilmiah. Dalam makalah ini juga akan coba dibahas mengenai tema pokok sebuah proses penelitian. Tema pokok ini akan dijabarkan secara logis dan kronologis dari metode keilmuan.
\end{abstract}

Kata Kunci: Struktur penelitian, penulisan ilmiah, teknik penulisan ilmiah

\section{PENDAHULUAN}

Penulisan ilmiah merupakan argumentasi penalaran keilmuan yang dikomunikasikan lewat bahasa tulisan. Untuk itu mutlak diperlukan penguasaan yang baik mengenai hakikat keilmuan agar dapat melakukan penelitian dan sekaligus mengkomunikasikannya secara tertulis

Tidak lagi menjadi soal dari mana akan memulai sebuah tulisan, sebab penguasaan tematis da teknik akan menjamin suatu keseluruhan bentuk yang utuh. Demikian juga bagi seorang penulis ilmiah yang baik, tidak jadi masalah apakah

\footnotetext{
*widya.fis57@gmail.com
} 
hipotesis ditulis langsung setelah perumusan masalah, ditempat mana akan dinyatakan postulat, asumsi atau prinsip, sebab dia tahu benar hakikat dan fungsi unsure-unsur tersebut dalam keseluruhan struktur penulisan ilmiah.

Lain dengan mereka yang belum menguasai logika penalaran ilmiah secara baik dan dengan demikian memperlakukan bentuk dan cara penulisan secara kaku. Bagi mereka, materi dalam pedoman merupakan sesuatu yang tidak dapat ditawartawar lagi, urutan dan langkahnya merupakan harga mati. Lalu muncullah umpanya keharusan-keharusan penulisan, yang sebenarnya padahal yang satu adalah logis dan bahkan imperative, namun dalam hal lain adalah tidak perlu dan kadang-kadang dipaksakan. Umpamanya karena ada keharusan mencantumkan asumsi, sedangkan dalam sekuruh kerangka argumentasi keilmuan tersebut tidak memerlukan adanya asumsi tertentu, maka pengajuan asumsi tersebut tidak perlu. Sama halnya dengan pencantuman postulat dan prinsip, sekiranya perlu maka hal ini memang harus tersurat, namun jangan terlalu dipaksakan dan dibuat-buat, sebab yang paling penting bukan ada atau tidaknya, atau dituliskannya dibagian mana, melainkan untuk apa serta dalam kaitannya dengan argumentasi mana keberadaan mereka tersebut mempunyai makna.

\section{Struktur Penelitian dan Penulisan Ilmiah}

\section{$>$ Pengajuan Masalah}

Langkah pertama dalam suatu penelitian ilmiah adalah mengajukan masalah. Satu hal yang harus disadari bahwa pada hakikatnya suatu masalah tidak pernah berdiri sendiri dan terisolasi dari factor-faktor lain. Selalu terdapat konstelasi yang merupakan latar belakang dari suatu masalah tertentu. Menurut Riduan (2008) bahwa latar belakang masalah dalam penelitian menjelaskan mengapa masalah yang diteliti itu timbul dan penting dilihat dari segi profesi peneliti, pengembangan ilmu dan kepentingan tertentu. Secara operasional suatu gejala baru dapat disebut masalah bila gejala itu terdapat dalam situasi tertentu.

Latar belakang masalah menyajikan hal-hal berikut yang dikemukakan oleh Riduan (2008):

a. apa saja yang membuat peneliti merasa gelisah dan resah sekiranya masalah tersebut tidak diteliti, 
b. gejala-gejala kesenjangan yang terdapat dilapangan sebagai dasar pemikiran untuk memunculkan masalah,

c. kerugian-kerugian apa yang yang bakal diderita jika tidak diteliti dan keuntungan-keuntungan apa kiranya jika diteliti,

d. kedudukan masalah yang hendak diteliti itu dalam wilayah bidang studi yang ditekuni oleh peneliti yang bersangkutan,

e. keadaan atau fakta actual yang menarik perhatian penulis untuk diteliti.

Dalam panduan penulisan tesis dan disertasi Universitas Negeri Padang menjelaskan bahwa penulisan latar belakang masalah bermula dari pemaparan tentang hal-hal ideal dan diharapkan terjadi, kemudian diikuti dengan penyajian hail amatan awal yang berupa fenomena lapangan. Selanjutnya penulis menjelaskan eksistensi kesenjangan antara harapan dan kenyataan dan ditutup dengan pernyataan atau penegasan tentang masalah utama penelitian dan perlunya penelitian itu dilakukan.

Selanjutnya dalam konstelasi yang bersifat situasional inilah maka dapat mengidentifikasikan obyek yang menjadi masalah. Identifikasi masalah merupakan suatu tahap permulaan dari penguasaan masalah dimana suatu objek dalam suatu jalinan situasi tertentu dapat dikenali sebagai suatu masalah. Identifikasi masalah berisi semua dalam objek, baik yang akan diteliti maupun yang tidak akan diteliti.

Melihat banyak masalah yang teridentifikasi dalam identifikasi masalah, maka permasalahan tersebut perlu dibatasi ruang lingkupnya. Pembatasan masalah merupakan upaya untuk menetapkan batas-batas permasalahan dengan jelas. Pemabatasan maslah dilakukan agar penelitian lebih terarah, terfokus dan tidak melenceng kemana-mana.

Dari pembatasan masalah ini memungkinkan peneliti merumuskan masalah dengan baik. Perumusan masalah merupakan upaya untuk menyatakan secara tersurat pernyataan-pernyatan apa saja yang ingin peneliti carikan jawabannya. Perumusan masalah dijabarkan dari identifikasi dan batasan masalah, dengan kata lain perumusan masalah merupakan pernyataan lengkap dan terperinci mengenai ruang lingkup permasalahan yang akan diteliti berdasarkan identifikasi dan pembatasan masalah. 
Setelah masalah berhasil dirumuskan dengan baik, maka seorang peneliti menyatakan tujuan penelitiannya. Tujuan penelitian ini adalah pernyataan mengenai ruang lingkup dan kegiatan yang akan dilakukan berdasarkan masalah yang telah dirumuskan. Setelah itu dibahas kemungkinan kegunaan penelitian yang merupakan manfaat yang dapat diperoleh dari pemecahan masalah yang didapat dari penelitian.

Dengan demikian maka secara kronologis terdapat enam kegiatan dalam langkah pengajuan masalah sebagaimana yang sudah dijelaskan di atas yaitu:

a. latar belakang masalah

b. identifikasi masalah

c. pembatasan masalah

d. perumusan masalah

e. tujuan penelitian

f. keguanaan penelitian

\section{$>$ Penyusunan Kerangka Teoritis}

Setelah masalah berhasil dirumuskan dengan baik maka langkah kedua dalam metode ilmiah adalah mengajukan hipotesis. Hipotesis merupakan dugaan atau jawaban sementara terhadap permasalahan yang diajukan. Cara menyelesaikan masalah dalam kajian ilmiah adalah dengan mempergunakan pengetahuan ilmiah sebagai dasar argumentasi dalam mengkaji persoalan agar kita mendapatkan jawaban yang dapat diandalkan.

Pengkajian teori ilmiah ini dilakkukan untuk menjawab hipotesis. Seperti diketahui bahwa pada hakikatnya metode ilmiah dapat disimpulkan ke dalam dua langkah utama yakni, pertama, pengajuan hipotesis yang merupakan kerangka teoritis yang secara dedektif dijalin dari pengetahuan yang dapat diandalkan dan, kedua, pengumpulan data secara empiris untuk menguji apakah kenyataan yang sebenarnya mendukung atau menolak hipotesis tersebut.

Agar sebuah kerangka teoritis dapat disebut meyakinkan maka argumentasi yang disusun tersebut harus dapat memenuhi beberapa syarat (Suriasumantri, 1993): pertama, teori-teori yang digunakan dalam membangun kerangka teoritis harus merupakan pilihan dari sejumlah teroi yang dikuasi secara lengkap dengan mencakup perkembangan-perkembangan terbaru. Sebagaimana 
diketahui bahwa dalam sebuah disiplin ilmu kadang-kadang terdapat lebih dari satu pendekatan yang tercermin dalam berbagai teori dalam mendekati persoalan yang sama. Demikian juga jika terdapat beberapa aliran dalam sebuah pendekatan maka harus dikemukakan alasan mengapa memilih aliran tertentu dan tidak aliran yang lain. Di samping itu perlu juga disadari bahwa ilmu berkembang dengan cepat dan sebuah teori yang bersifat efektif pada suatu saat mungkin akan ditinggalkan pada saat yang lain. Oleh sebab itu maka pengetahuan mengenai teori-teori yang akan dipergunakan harus sudah mencakup perkembanganperkembangan terbaru di bidangnya.

Kedua, analisis filsafat dari teori-teori keilmuan yang difokuskan kepada cara berpikir keilmuan yang mendasari pengetahuan tersebut dengan pembahasan secara eksplisit mengenai postulat, asumsi dan prinsip yang mendasarinya. Ketiga, mampu mengidentifikasikan masalah yang timbul sekitar disiplim ilme tersebut

Kerangka pemikiran ini merupakan penjelasn sementara terhadap gejala yang menjadi objek permasalahan. Kerangka pemikiran yang berupa penjelasan sementara ini merupakan argumentasi dalam merumuskan hipotesis yang merupakan jawaban sementara terhadap permasalahan yang diajukan. Criteria utama agar suatu kerangka pemikiran bisa meyakinkan sesame ilmuan adalah alur-alur pikiran yang logis dalam membangun suatu kerangka berpikir yang membuahkan kesimpulan yang berupa hipotesis. Pada hakikatnya kerangka berpikir dalam pengajuan hipotesis didasarkan kepada argumentasi berpikir deduktif dengan mempergunakan pengetahuan ilmiah, sebagai premis-premis dasarnya.

Selain premis-premis tersebut, dalam kerangka teoritis juga perlu melakukan pengkajian terhadap penelitian-penelitian yang relevan yang telah dilakukan oleh peneliti lain. Hal ini dilakukan pertama-tama disebabkan oleh sifat ilmu yang pengembangannya dilakuakn secara kumulatif. Hal ini disamping akan menghindari adanya duplikasi yang sia-sia, juga akan memberikan perspektif yang jelas menganai hakikat dan keguanaan penelitian dalam perkembangan secara keseluruhan. Demikian juga hasil penelitian mutkhir, mungkin merupakan pengetahuan teoritis yang baru atau revisi terhadap teori lama, yang dapat dipergunakan sebagai premis dalam penyususnan kerangka pemikiran maupun 
dalam kegiatan analisis yang lain, umpamanya saja dalam pembahasan mengenai kesimpulan analis data.

Kerangka teoritis suatu penelitian dimulai dengan mengidentifikasikan dan mengkaji berbagai teori yang relevan serta diakhiri dengan pengajuan hipotesis. Bahwa produk akhir dari proses pengajuan kerangka teoritis ini adalah perumusan hipotesis serta merupakan pangkal dan tujuan dari seluruh analisis. Hal ini harus tercermin bukan saja dalam struktur logika berpikir melainkan juga dalam struktur penulisan.

Secara ringkas langkah dalam penysunan kerangka teoritis dan pengajuan hipotesis ini dapat dibagi dalam kegiatan-kegiatan berikut:

a. Pengkajian mengenai teori-teori ilmiah yang akan dipergunakan dalam analisis

b. Pembahasan mengenai penelitian-penelitian lain yang relevan

c. Penyusunan kerangka berpikir dalam pengajuan hipotesis dengan mempergunakan premis-premis

d. Perumusan hipotesis

\section{$>$ Metodelogi Penelitian}

Setelah merumuskan hipotesis yang diturunkan secar deduktif dari pengetahuan ilmiah yang relevan maka langkah berikutnya adalah menguji hipotesis tersebut secara empiris. Artinya melakukan verifikasi apakah pertanyaan yang dikandung oleh hipotesis yang diajukan tersebut didukung atau tidak oleh kenyataan yang bersifat factual. Kalau dalam proses pengajuan hipotesis peneliti dituntut untuk melakukan penarikan kesimpulan secara deduktif maka dalam proses verifikasi peneliti dituntut untuk melakukan penarikan kesimpulan secara induktif. Proses verifikasi ditujukan kepada upaya untuk menarik kesimpulan yang bersifat umum dari fakta-fakta yang bersifat individual. Masalah yang dihadapi dalam proses verifikasi ini adalah bagaimana prosedur dan cara dalam pengumpulan dan analisis data agar kesimpulan yang ditarik memenuhi persyaratan berpikir induktif. Penetapan prosedur dan cara ini disebut metodelogi penelitian yang pada hakikatnya merupakan persiapan sebelum verifikasi dilakukan

Metodologi adalah pengetahuan tentang metode-metode, jadi metodologi penelitian adalah pengetahuan tentang berbagai metode yang dipergunakan dalam 
penelitian. Salah satu metode yang harus ditentukan dalam metodologi penelitian adalah metode penelitian. Setiap penelitian pada hakikatnya mempunyai metode penelitian masing-masing dan metode penelitian tersebut ditetapkan berdasarkan tujuan penelitian. Oleh sebab itu maka kegiatan pertama dalam penyusunan metodologi penelitian adalah menyatakan secara lengkap dan operasional tujuan penelitian yang mencakup bukan saja variable-variabel yang akan diteliti dan karakteristik hubungan yang akan diuji melainkan sekaligus juga tingkat keumuman dari kesimpulan yang akan ditaris seperti tempat, waktu, kelembagaan dan sebagainya. Berdasarkan tujuan penelitian ini maka peneliti dapat memilih metode penelitian yang tepat beserta teknik pengambiln contoh dan teknik penarikan kesimpulan yang relevan. Metode adalah prosedur atau cara yang ditempuh dalam mencapai suatu tujuan tertentu yang ditemui dalam melaksanakan prosedur. Jadi sebuah metode penelitian mencakup beberapa teknik yang termasuk di dalamnya teknik pengambilan contoh, teknik pengukuran, teknik pengumpulan data dan teknik analisa data.

Dalam teknik pengumpulan data harus dinyatakan variable yang akan dikumpulkan, sumber data dari mana keterangan variable tersebut didapatkan. Demikian juga halnya yang menyangkut teknik pengukuran, instrumn pengukuran dan teknik mendapatkan data. Sekiranya pengumpulan data memerlukan instrument tertentu maka instrument yang akan dipergunakan harus diuji dahulu sebelum dipergunakan. Instrument harus teruji mengenai keabsahan (validitas) dan keandalannya (reliable).

Pada dasarnya data beru dikumpulkan setelah instrumennya sah memenuhi persyaratan secara apriori dan bukan aposteriori. Untuk itu maka data pengujian instrument cukup dinyatakan secara singkat pada metodelogi penelitian dan bukan pada hasil penelitian. Sekiranya diperlukan maka data yang lebih lengkap dapat ditempatkan dalam lampiran. Demikian juga halnya dengan berbagai persiapan lainnya seperti tes pendahuluan dalam teknik pengambilan contoh.

Secar ringkas makal langkah dalam penyusunan metodologi penelitian mencakup kegiatan-kegiatan sebagai berikut: 
a. tujuan penelitian secara lengkap dan operasional dalam bentuk pernyataan yang mengidentifikasikan variable-variabel dan karakteristik hubungan yang akan diteliti

b. tempat dan waktu penelitian dimana akan dilakukan generalisasi mengenai variable-variabel yang diteliti

c. metode penelitian yang ditetapkan berdasarkan tujuan penelitian dan tingkat generalisasi yang diharapkan

d. teknik pengambilan contoh yang relevan dengan tujuan penelitian. Tingkat keumuman dan metode penelitian

e. teknik pengumpulan data yang mencakup identifikasikan variable yang akan dikumpulkan, sumber data, teknik pengukuran, instrument dan teknik mendapatkan data

f. teknik analisis data yang mencakup langkah-langkah dan teknik analisis yang dipergunakan yang ditetapkan berdasarkan pengajuan hipotesis.

\section{$>$ Hasil Penelitian}

Dalam membahas hasil penelitian maka harus selalu diingat bahwa tujuan nya adalah membandingkan kesimpulan yang ditarik dari data yang dikumpulkan dengan hipotesis yang diajukan. Secara sistematik dan teroarh maka data yang dikumpulkan tersebut diolah, dideskripsikan, dibandingkan dan dievaluasi yang kesemuanya diarahkan kepada sebuah penarikan kesimpulan apakah data tersebut mendukung atau menolak hipotesis yang diajukan. Pada hakikatnya sebuah hasil penelitian yang baik tidak berhenti pada kesimpulan apakah sebuah hipotesis diterima atau ditolak melainkan dilengkapi dengan evaluasi mengenai kesimpulan tersebut. Evaluasi yang mencakup masalah-masalah dapat menjadi saran-saran yang bermanfaat bagi peneliti lain yang mungkin berminat untuk mengkaji masalah itu lebih lanjut.

Untuk melaporkan hasl penelitian maka secara singkat dan kronologis pertama-tama diberikan deskripsi tentang variable yang diteliti yang disusul dengan teknik analisis yang dipergunakan. Setelah itu hasil pengukuran dilaporkan yang kemudian dilengkapi dengan kesimpulan analisis dari data yang telah dikumpulkan. Laporan ditulis dalam bentuk esai dengan kalimat-kalimat verbal yang mencakup semua pernyataan yang sepatutnya dikemukakan baik 
pernyataan yang bersifat kualitatif maupun kuantitatif. Sekiranya diperlukan, maka deskripsi dalam bentuk esai ini dilengkapi dengan berbagai sarana pembantu seperti tabel, grafik, atau bagan yang berfungsi untuk lebih menjelaskan pernytaan yang terkandung dalam esai. Perlu diingat bahwa tabel, grafik atau bagan itu fungsinya adalah membantu menperjelas pernyataan-pernyataan verbal bukan sebaliknya. Seringkali didapatkan laporan penelitian yang issnya adalh sejumlah tabel, grafik atau bagan dengan penjelasan yang sangat minimal.

Demikian juga data yang ditempatkan dalam tubuh utama laporan harus merupakan data yang telah diolah. Data mentah dan langkah-langkah dalam pengolahan data tersebut sebaiknya ditulis dalam lampiran.

Langkah berikutnya adalah memberikan penafsiran terhadap kesimpulan analisis data. Pada hakikatnya dalam langkah ini harus menafsirkan hubungan yang bersifat statistis seperti regresi dan korelasi dalam hubungan yang bersifat ilmiah seperti hubungan kausalita. Demikian juga harus menafsirkan tingkat keumuman dari kesimpulan yang ditarik berdasarkan contoh kepada kesimpulan yang menyangkut populasi. Seorang peneliti akhirnya harus dapat menafsirkan sebuah kesimpulan akhir yang ditarik dari analisis yang telah dilakuakan. Hasil penafsiran ini kemudian dibandingkan dengan hipotesis yang diajukan untuk menyimpulkan apakah hipotesis tersebut ditolak atau diterima.

Secara singkat maka hasil penlitian dapat dilaporkan dalam kegiatan sebagai berikut:

a. menyatakan variable-variabel yang diteliti

b. menyatakan teknik analisis data

c. mendeskripsikan hasil analisis data

d. memberikan penafsiran terhadap kesimpulan terhadap kesimpulan analisis data

e. menyimpulakn pengujian hipotesis apakah ditolah atau diterima.

\section{$>$ Ringkasan dan Kesimpulan}

Kesimpulan hipotesis kemudian dikembangkan menjadi kesimpulan penelitian yang ditulis dalam bab tersendiri. Kesimpulan penelitian merupakan sintesis dari keseluruahan aspek penelitian yang terdiri dari masalah, kerangka teoritis, hipotesis, metodologi penelitian, dan penemuan penelitian. Sistesis ini merupakn buah kesimpulan yang ditopang oleh suatu kajian yang bersifat terpadu 
dengan meletakkan berbagai aspek penelitian dalam perspektif yang menyeluruh. Untuk itu dari aspek-aspek tersebut diuraikan kembali secara ringkas peryataanpernyataan pokok dari aspek-aspek tersebut di atas dengan meletakkannya dalam kerangka yang mengarahkan kepada kesimpulan. Itulah sebabnya maka bab ini disebut ringkasan dan kesimpulan yang pada dasarnya mencerminkan hakikat yang disingkapkan oleh penelitian.

Peneliti harus mamapu menarik kesimpulan yang utuh dari data yang bersifat terpisah dengan tidak meninggalkan sifat keilmuan. Kesimpulan penelitian ini harus tetap dapat dipertanggungjawabkan dalam kerangka teoritis keilmuan yang didukung oleh penemuan penelitian. Kesimpulan ini kemudian dibahas dengan jalan membandingkannya terhadap penelitian lain serta pengetahuan ilmiah yang relevan.

Berdasarkan analisis tersebut maka seorang peneliti dapat melihat berbagai implikasi yang ditimbulakan oleh kesimpulan penelitian. Implikasi ini umpamanya bisa berupa pengembanagn ilmu, keguanaan terapan yang bersifat praktif dan penyusunan kebijaksanaan. Hal ini kemudian dijabarkan dalam serangkaian tindakan yang berupa saran-saran.

Dengan demikian maka bab mengenai ringkasan dan kesimpulan dapat diperinci ke dalam langkah-langkah sebagai berikut:

a. deskripsi singkat mengenai masalah, kerangka teoritis, hipotesis, metodelogi dan penemuan penelitian

b. kesimpulan penelitian yang merupakan sintesis berdasarkan keseluruhan aspek tersebut di atas

c. pembahasan kesimpulan penelitian dengan melakukan perbandingan terhadap penelitian lain dan pengetahuan ilmiah yang relevan

d. mengkaji implikasi penelitian

e. megajukan saran

\section{$>$ Abstark}

Seluruh laporan penelitian kemudian disarikan dalam sebuah ringkasan yang disebut abstrak. Abstrak merupakan ringkasan seluruh kegiatan penelitian yang paling banyak terdiri dari tiga halaman. Keseluruhan abstrak merupakan sebuah esai yang utuh dan tidak dibatasi oleh subjudul. Hanya terdapat satu judul 
dalam abstrak yakni judul penelitian. Sesuai dengan langkah-langkah dalam kegiatan penelitian maka abstrak mencakup keseluruhan pokok pernyataan penelitian mengenai masalah, hipotesis, metodologi dan kesimpulan penelitian. Kerangka pemikiran dalam pengajuan hipotesis karena biasanya terlalu panjang tidak dicantumkan dalam abstrak.

Dengan demikian abstrak merupakan sebuah esai yang terdiri dari serangkaian paragraph yang secara keseluruhan mampu mengkomunikasikan intisari sebuah penelitian. Tiap bagian harus mendapatkan perlakuan yang seimbang. Abstrak berfungsi memberikan gambaran secara keseluruhan. Dari sebuah abstrak dapat disimpulkan apakah kita berminat untuk membaca keseluruhan laporan atau tidak. Abstrak dapat diibaratkan sebuah iklan yang kita taruh di halaman terdepan dari publikasi ilmiah dengan tujuan agar iklan tersebut mampu mengkomunikasikan apa yang disajikan.

\section{$>$ Daftar Pustaka}

Sebuah laporan penelitian dilengkapi dengan daftar pustaka yang merupakan sumber referensi bagi seluruh kegiatan penelitian. Pada hakikatnya daftar pustaka merupakan inventarisasi dari seluruh publikasi ilmiah maupun nonilmiah yang digunakan sebagai dasar bagi pengkajian yang dilakukan.

\section{$>$ Riwayat Hidup}

Riwayat hidup ini biasanya merupakan deskripsi dari latar belakang pendidikan dan pekerjaan yang mempunyai hubungan dengan penulisan ilmiah yang disampaikan. Tidak perlu mencantumkan hal-hal yang kurang relevan dengan penulisan. Semua hal penting tersebut diringkas dalam satu atau dua halaman tulisan. Riwayat hidup dicantumkan pada halaman terakhir sebuah laporan tanpa diberi nomor halaman

\section{$>$ Usulan Penelitian}

Sebuah usulan penelitian mengandung seluruh langkah-langkah penelitian tersebut diatas tanpa hasil penelitian, sebab hal ini baru akan dilakukan. Dengan demikian usulan penelitian hanya mencakup langkah pengajuan masalah, penyusunan kerangka teoritis dan pengajuan hipotesis sert metodologi penelitian. 
Usulan penelitian dilengkapi dengan jadwal kegiatan, personalia peneliti serta aspek-aspek lainnya yang berhubungan dengan penelitian umpamanya pembiayaan.

\section{Lain-lain}

Sebelum memasuki tubuh utama laporan sebuah tulisan ilmiah biasanya didahului oleh beberapa informasi yang bersifat pengantar. Pertama-tama tentu saja adalah halaman judul dari laporan ilmiah tersebut. Judul tersebut harus singkat namun mampu mengkomunikasikan tentang masalah yang diteliti, dilakukan dimana, kapan serta kalau mungkin metode penelitian apa.

Setelah itu dikemukakan secara umum lingkup laporan yang akan disampaikan beserta penghargaan terhadap berbagai pihak yang telah membantu penyelesaian karya ilmiah tersebut. Kemudian menyusun daftar isi yang dilengkapi dengan daftar tabel dan daftar gambar yang disusun secara tersendiri. Untuk tesis dan disetasi disisipkan lembar persetujuan para pembimbing serta pihak lainnya. Semua materi yang terdapat pada bagian lain-lain diberi nomor halaman dengan menggunakan angka latin yang ditulis dengan huruf kecil.

\section{Teknik Penulisan Ilmiah}

Teknik penulisan ilmiah mempunyai dua aspek yakni gaya penulisan dalam membuat pernyataan ilmiah serta teknik notasi dalam menyebutkan sumber dari pengetahuan ilmiah yang digunakan dalam penulisan. Komunikasi ilmiah harus bersifat jelas dan tepat yang memungkinkan proses penyampaian pesan bersifat reproduktif dan impersonal. Bahasa yang digunakan harus jelas dimana pesan mengenai objek yang ingin dikomunikasikan mengandung informasi yang disampaikan sedemikain rupa sehingga si penerima betul-betul mengerti akan isi pesan yang disampaikan kepadanya.

Tata bahasa merupakan ekspresi dari logika berpikir. Oleh karena itu maka langkah pertama dalam menulis karangan ilmiah yang baik adalah mempergunakan tata bahas yang benar. Demikian juga penggunaan kata harus dilakukan secara tepat artinya harus memilih kata-kata yang sesuai dengan pesan yang ingin disampaikan. 
Pengetahuan ilmiah penuh dengan terminology-terminologi yang memerlukan penafsiran berbeda antara seorang ilmuan dengan ilmuan lainnya. Untuk menghindari salah tafsir itu maka sebaiknya peneliti menjelaskan pengertian yang dikandung oleh terminologi yang peneliti pilih. Penjelasan ini pada hakikatnya berlaku pada seluruh proses komunikasi ilmiah. Kadang-kadang bahkan terminology yang kelihatannya seakan-akan sudah jelas dan gambling juga membutuhkan penjelasan. Penjelasan ini diperlukan sebab terdapat pengertian yang banyak sekali mengenai apa yang dimaksudkan orang dengan pengertian tersebut. Intensitas penjelasan ini harus sepadan dengan tujuan komunikasi.

Komunikasi ilmiah harus bersifat reproduktif, artinya bahwa si penerima pesan mendapatkan copy yang benar-benar sama dengan prototype yang disampaikan si pemberi pesan. Dalam komunikasi ilmiah tidak boleh terdapat penafsiran yang berbeda terhadap objek komunikasi yang sama, yang disebabkan oleh penjiwaan yang berbeda terhadap objek estetik yang diungkapkan. Komunikasi ilmiah ditujukan pada penalaran dan oleh sebab itu harus dihindarikan setiap bentuk pernyataan yang tidak jelas dan bermakna jamak. Selain itu juga harus dihindari bentuk komunikasi yang mempunyai konotasi emosional.

Komunikasi ilmiah harus bersifat impersonal. Kata ganti perorangan hilang dan ditempati oleh kata ganti universal yakni “ilmuan”. Proses pengumpulan data tidak dinyatakan dengan kalimat seperti “saya bermaksud mengumpulkan data dengan menggunakan kuisioner” melainkan dengan kalimat yang impersonal yakni "data akan dikumpulakan dengan mempergunakan kuisioner” dalam hal ini maka yang mengumpulkan data adalah ilmuan atau peneliti yang tidak disampaikan secara tersurat.

Pernyatan ilmiah yang dipergunakan dalam tulisan harus mencakup beberapa hal. Pertama, harus dapat diidentifikasikan orang yang membuat pernyataan tersebut. Kedua, harus dapat diidentifikasikan media komunikasi ilmiah dimana pernyataan tersebut disampaikan apakah itu makalah, buku, seminar, lokakarya atau sebagainya. Ketiga, harus dapat diidentifikasikan lembaga yang menerbitkan publikasi ilmiah tersebut beserta tempat berdomisili dan waktu 
penerbiatan itu dilakukan. Sekiranya pernyataan ilmiah itu tidak diterbitkan melainkan disampaikan dalam bentuk makalah atau seminar atau lokakarya maka harus disebutkan tempat, waktu dan lembaga yang melakukan kegiatan tersebut.

Ketiga cara di atas dalam tulisan ilmiah disebut teknik notasi ilmiah. Terdapat bermacam-macam teknik notasi ilmiah yang pada dasarnya mencerminkan hakikat dan unsure yang sama meskipun dinyatakan dalam format dan symbol yang berbeda-beda. Di dunia keilmuan dikenal beberapa teknik notasi ilmiah yang diakui secara internasional. Perguruan-perguruan tinggi tertentu biasanya membuat teknik notasi ilmiah sendiri yang merupakan pedoman penulisan ilmiah di lingkungannya. Pada dasarnya seorang ilmuan boleh memilih salah satu dari teknik notasi ilmiah yang telah diakui asalakan dilakukan secara konsisten.

Dalam teknik notasi ilmiah dengan menggunakan catatan kaki, terdapat dua variasi. Variasi pertama ialah bahwa catatan kaki itu ditaruh dalam halaman yang sama, sedangkan variasi yang kedua catatan kaki itu seluruhnya dikelompokkan dan ditaurh pada akhir sebuah bab.

Memilih variasi harus disesuaikan dengan fungsi dari catatan kaki tersebut. Fungsi pertama dari catatan kaki adalah sebagi sumber informasi bagi pernyataan ilmiah yang dipakan dalam tulisan ilmiah. Maka untuk hal ini adalah lebih baik jika menggunakan variasi catatan kaki yang ditaruh diakahir bab.

Fungsi kedua dari catatan kaki adalah sebagai tempat bagi catatan kecil. Dalam hal ini adalah lebih baik memilih variasi catatan kaki yang diletakkan dihalaman yang sama.

Sekiranya dalam penulisan ilmiah terdapat pernyataan orang lain. Kutipan yang dipinjam tersebut dapat berupa kutipan langsung atau kutipan tidak langsung. Kutipan langsung merupakan pernyataan yang dituliskan dalam karya ilmiah dengan susunan kalimat aslinya tanpa mengalami perubahan sedikitpun. Sedangkan kutipan tidak langsung adalah dengan mengubah susunan kalimat yang asli dengan susunan kalimat sendiri.

Pada hakikatnya seorang ilmuan harus mampu menyatakan pendapat orang lain dalam bahasa sendiri yang mencirikan kepribadian penulis. Oleh sebab itu karya ilmiah yang dipenuhi oleh kutipan langsung yang terlalu banyak tidak 
mencerminkan kepribadian penulis melainkan sekedar koleksi pendapat orang lain. Sebaiknya kutipan langsung intensitasnya tidak melebihi 30 persen dari seluruh kutipan yang ada. Semua kutipan baik langsung maupun tidak langsung biasanya diterjemahkan ke dalam bahasa pengantar yang dipakai.

Kutipan langsung memang diperlukan dengan tujuan untuk mempertahankan keaslian pernyataan itu. Seorang mungkin membuat pernyataan sangat otentik yang bisa disalin ke dalam bentuk pernyataan yang lain akankehilangan keotentikannya. Gabungan anatar kutipan langsung dan tidak langsung sering digunakan untuk memadukan antara penulisan seseorang dengan pernyataan orang lain yang ingin dipertahankan keasliannya. Kutipan langsung yang jumalahnya kurang dari empat baris ditaruh dalam tubuh tulisan dengan menggunakan tanda kutip. Untuk kutipan langsung yang terdiri dari emapt baris atau lebih maka keseluruhan kutipan tersebut ditaruh dalam tempat tersendiri.

\section{Kesimpulan}

Struktur penelitian dan penulisan ilmiah terdiri dari pengajuan masalah, kerangka teoritis, metodologi penelitian, hasil penelitian, ringkasan dan kesimpulan. Selain itu terdapat juga abstrak, daftar pustaka, daftar riwayat hidup dan lain-lain yang berisi halaman judul dan daftar isi, atbel, dan gambar.

Teknik penulisan ilmiah mempunyai dua aspek yakni gaya penulisan dalam pembuatan pernyatan ilmiah dan teknik notasi ilmiah dalam menyebutkan sumber dari pengetahuan ilmiah.

\section{Daftar Pustaka}

PPS UNP. 2009. Buku Panduan Penulisan Tesis dan Disertasi. Padang: UNP

Riduwan. 2008. Belajar Mudah Penelitian untuk Guru, Karyawan dan Peneliti Pemula. Bandung: Alfabeta

Suriasumantri, Jujun S. 1993. Filsafat Ilmu Sebuah Pengantar Popoler. Jakarta: Karya Uni Press 